\title{
What is Being Said About Internal Marketing? A Study of the Brazilian Business Administration Academic Production
}

\author{
Fernanda Roda de Souza Araújo Cassundé ${ }^{\dagger}$ \\ Universidade Federal do Vale do São Francisco \\ Nildo Ferreira Cassundé Junior ${ }^{\Omega}$ \\ Universidade Federal do Vale do São Francisco
}

\author{
Salomão Alencar de Farias ${ }^{*}$ \\ Universidade Federal de Pernambuco \\ José Ricardo Costa de Mendonça \\ Universidade Federal de Pernambuco
}

\begin{abstract}
This study had the purpose of identifying how internal marketing is being addressed in the Brazilian production in the field of Administration. To this end, the major periodicals in the field and the database of the National Association of Graduate Programs in Business Administration (Anpad) and Scientific Periodicals Electronic Library (SPELL) were investigated under the guidance of research propositions found in Farias (2010). After a search of the entire historical database of publications adopted as corpus, only 13 articles were discovered and retrieved from the period 1961-2012.The findings of this study show that the state of knowledge about internal marketing in Administration is quite specific and, in some cases, surprisingly nonexistent. This aspect allows us to notice various concerns, among which the most significant one is: for what reason has internal marketing not been receiving at least with respect to periodic and national Administration congresses - the attention it deserves? It is expected to contribute to the understanding of how scholars are studying the internal marketing of the area in the Brazilian context.
\end{abstract}

Keywords: Internal marketing. Endomarketing. Bibliometrics. State of knowledge.

Submitted on 02/25/2013; revised on 04/11/2013; accepted on 04/25/2013; disclosed on 10/21/2014

* Author for correspondence:

${ }^{\dagger}$ Master of Business

Administration from PROPAD-

Graduate Programme in

Administration from the

Federal University of

Pernambuco

Title: Assistant Professor at the

Federal University of Vale do

São Francisco

Address: Avenida José de Sá

Maniçoba, Petrolina - PE -

Brazil - E-mail:

fernanda.roda@univasf.edu.

br Phone: 2101.6853

Editor's Note: This paper was accepted by Emerson Mainardes.

$\begin{array}{ll}\text { - Master in Economics from } & { }^{¥} \text { PhD in Administration from } \\ \text { PIMES-Graduate Program in } & \text { the School of Economics and } \\ \text { Economics, Federal University } & \text { Administration, University of } \\ \text { of Pernambuco } & \text { São Paulo } \\ \text { Title: Assistant Professor at the } & \text { Link: Associate Professor at } \\ \text { Federal University of Vale do } & \text { the Federal University of } \\ \text { São Francisco } & \text { Pernambuco } \\ \text { Avenida Antonio Carlos } & \text { Address: Rua Rodrigues de } \\ \text { Magalhães, Juazeiro - } & \text { Mendonça, Recife - PE - } \\ \text { BA - Brazil - E-mail: } & \text { Brazil - E-mail: } \\ \text { nildo.cassunde@ univasf.edu.br } & \text { saf@ufpe.br } \\ \text { Phone: (74) 3614.1937 } & \text { Phone: (81) 2126-7174 }\end{array}$

$\mathrm{PhD}$ in Administration from Administration, University of

the Federal University of

Pernambuco

Phone: (81) 2126-7174
† PhD in Administration

from the School of

Administration of the

Federal University of Rio

Grande do Sul

Title: Associate Professor at

the Federal University of

Pernambuco

Address: BR-104 km 59,

Nova Caruaru Caruaru -

PE - Brazil

E-mail: jrcm@ufpe.br Phone: (81) 21267772 


\section{INTRODUCTION}

here are, in Brazilian literature specialized in Administration, various interpretations of what internal marketing is, since there are several terms used: "endomarketing" and marketing applied to human resources, as suggested by Farias (2010). However, according to said author, international literature "is clear in the use of a single term: internal marketing (IM)" (p .119). Thus, it becomes important to understand how Brazilian research in Administration has approached this concept (including highlighting which term is most commonly used), since, if the Brazilian Academy of Marketing unifies the term and the concept of internal marketing, it can avoid confusion (distortion) and even collaborate with the advancement of knowledge in this field (FARIAS, 2010).

In this sense, building a bibliometric study in an attempt to rescue what has been researched on the subject allows us to map and identify the ideas being discussed throughout the history of the most recognized events and national periodicals in Administration. So this article purports to give a perspective on this subject (internal marketing) in Administration, for it analyzes the articles published in leading and renowned Brazilian scientific periodicals in Administration and in the databases of the National Association of Graduate Studies and Research in Administration (Anpad) and Scientific Periodicals Electronic Library (SPELL).

The study adopts qualitative research procedures in order to describe critically the domestic production related to internal marketing in Administration. Thus, this study was guided by the following question: How are scholars studying internal marketing in the Brazilian context of Administration? The objective was therefore to conduct a search using meta-analysis, investigating and analyzing the theme, verifying methodological guidance and the demographics of authorship of all articles retrieved, totaling 13 in the online search system of events and publications (ANPAD and SPELL).

The results of this study can be used to analyze not only the current trends, but the historical scientific production in Administration, as well as to indicate the direction of future work.

\section{WHAT IS THE PURPOSE OF A STUDY ON THE BRAZILIAN PRODUCTION IN ADMINISTRATION?}

The "Academia in Administration in Brazil has many reasons to celebrate its performance in recent years: academic production has increased, and scholars have been more devoted to research" (KIRSHBAUM, PORTO; FERREIRA, 2004, p .7). The increase in 
administrative and organizational research provides not only the consolidation of Administration as an area of knowledge, with its own characteristics, but has also led to healthy reflections on the quality of scientific production in the field (LOPES; BERNARDES, 2001).

In view of Romanowski and Ens (2006) perspectives, the increase in the quantity of publications generates concerns and questions, such as: What are the most studied topics? What approaches have been used? Which are the relevant contributions of these publications to the area? What is being published about the topic? In this sense, as pointed out by Caldas, Tonelli and Lacombe (2002, p.1), as of the 90s the Brazilian Academy in Administration seems to have turned to itself, metastudies have emerged and multiplied, "analyzing the various dimensions of scientific literature in each of these areas"(CALDAS; TONELLI; LACOMBE, 2002 p. 1).

Not unlike other areas of knowledge, Administration has been changing at a very fast pace, so, due to this growth, it is necessary to periodically monitor the scope of studies conducted in a specific period of time, because the quantitative growth does not necessarily imply criteria for advancement in the field of research. So Ferreira (2002) and Cardoso et al. (2005) highlight the importance of mapping, discussing and knowing the academic production in a given field.

Despite the acknowledged importance, several studies indicate a low number of works produced in the country whose goal is to map and analyze the accumulated knowledge in a particular field (TEIXEIRA; MEGID NETO, 2006; CALDAS; TINOCO, 2004). Thus, while science is being built over time, privileging one aspect, one methodology and/or one theoretical referential, the analysis must also, from the understanding of Soares and Maciel (2000), be developed in parallel, identifying and explaining the paths of science. Thus the process of building knowledge about a certain topic is revealed in an attempt to integrate the results and identify overlaps, contradictions and especially gaps, that is, unexplored aspects.

\subsection{INTERNAL MARKETING: BEYOND A SIMPLE MEANING}

Considering the increase of competitiveness in recent decades and the search for the provision of high quality services as a competitive advantage, company staff began to receive greater importance from managers, since it became understood that the motivation of employees could impact on service provision and hence on the perception of customer satisfaction (KURTZ; CLOW, 1996). Papasolomou (2006) reinforces the idea of previous 
authors when he stresses that organizations that select, develop, manage and motivate their workforce have an extraordinary competitive advantage over those that do not.

Thus, depending on the importance of internal marketing mentioned by Kurtz and Clow (1996) and Papasolomou (2006), and the debate proposed by Farias (2010), it is important to introduce the concept of internal marketing in an attempt to clarify any misinterpretations.

In this sense, Farias (2010, p. 107) draws attention to the fact that "approximately 34 years ago the internal marketing (IM) was proposed consistently as a solution to the problem of provision of high quality services by Berry et al. (1976) ". As for Grönroos (2006), the concept of internal marketing originated from marketing services research. Varey and Lewis (1999) go further and call attention to the fact that said concept comes from discussions originated in the early years of the twentieth century. In other words, based on the original propositions of marketing management focused on the external market, with the development of knowledge in the area of services, the proposition of internal marketing in the management of services arises Thus, the application of marketing tools in the interaction between companies and employees is not limited to the "p" as in promotion (communication), but to the management of the traditional marketing mix in a unique process of exchange (organization-employees), with the challenge of seeking balance between product supply (title), price (wage, costs), place (workplace) and promotion (communication), so that the employee is satisfied with the internal exchanges and can deliver better service to the external customer.

It seems that the essence of internal marketing is not a phenomenon of the postindustrial era, since there is some evidence of attitudes and methods in the early literature of marketing and management indicating that programs to generate the commitment between employees and the company's objectives are not recent. Thus, even though it is not a new concept, it is a condition that could lead to confusion in interpretation, as internal marketing still lacks conceptual clarity, and a vast literature has been examined containing a number of concerns regarding limitations of its concept (VAREY, LEWIS, 1999). Therefore, there remains a certain conflict in literature regarding the understanding of what internal marketing is and what actions should be taken to implement it.

Although many definitions of internal marketing see the term either as a concept or as a philosophy or management practice in relation to the management of human resources, to marketing services and to change management (LINGS, BROOKS, 1998, p. 327), much of the early work on internal marketing focused on motivation and employee satisfaction, as it 
was believed that, to the extent that an organization satisfies its employees, its customers would also be satisfied, since the product in service companies is manpower (FARIAS, 2010). In this sense Papasolomou (2006) believes that the goal of internal marketing is to make employees-customers motivated in order to achieve service excellence. For Berry et al. (1976), which seems to us the best definition, internal marketing is focused on providing domestic product (tasks) that satisfy the needs of a vital internal market (employees), provided that the organization's goals are met. This concept is complemented by Greene et al. (1994, p. 8), when they argue that internal marketing is viewing employees as internal customers, tasks as internal products, and it is engaging in designing these products to better meet the needs of such customers.

Varey and Lewis (1999) also emphasize the importance of the work of Rafiq and Ahmed (1993), showing characteristics of the usual thought and assumptions of the discussion about internal marketing.

Thus, we can see how the internal marketing gains prestige and widely contributes to increase the levels of involvement and commitment of collaborators, particularly service businesses (ORFÃO, 2010).

In this sense, there are many authors (GRÖNROOS, 2006; BERRY et al., 1976; FARIAS, 2010; LION et al., 2010; ORPHAN, 2010) that associate internal marketing to the context of service marketing. Besides seeming to be unquestionable that the prospect of internal marketing gained primordial space in management, in recent times, it is also understood that "today the marketing [...] depends largely on the attitudes, behavior and performance of everybody that composes an organization, especially those who interact with customers "(Lion et al., 2010, p. 69), thus directly impacting on organizational success, because in each interaction (employee-customer) there is potential risk of generating satisfaction (or not), contributing to the solidification (or wear) of the relationship with the customer, the authors emphasize. Normann (1977, 1993) played a key role in such relationship when he established the "moments of truth" in services, that is, when there is direct contact between the service provider and the customer (interactive marketing). It is common to find in the traditional marketing literature the issue of representation of the relationship of the internal marketing with traditional marketing, which leads to interactive marketing (present in services), according to which the employee relates to the external customer. 
Notably, interest in marketing services in the last 20 years is related to the economic importance of the post-industrial era, since, considering globalization and that the possibilities of differentiation are reduced when thinking only about products, there arises a need to develop competitive advantages focused on the provision of services. Given the trajectory of development of research in the field, the increase in publications on the subject (in Brazil or abroad), the existence of several specialized periodicals on the subject, and especially the awareness that society is essentially consuming services (rather than products), it is possible to notice the consolidation and importance of marketing services and consequently of internal marketing for the management of organizations.

\subsection{AND WHAT ABOUT THE SCIENTIFIC PRODUCTION IN ADMINISTRATION IN BRAZIL?}

It is not possible to dissociate the development of academic research in Administration from the development of graduate studies in the field, "from which is recorded substantial part of the scientific production of teachers and students" (BERTERO; CALDAS; WOOD JR, 1999, p. 150).

So, to review scientific literature, it is necessary to consider the context in which graduate courses are developed. Importantly, the model adopted for the implementation and development of graduate programs in Brazil was related directly to the production of scientific knowledge. Such a model, of Germanic origin, "arrived with the University Reform of 1968 and left the indissoluble union between teaching and research", as propose Bertero, Caldas and Woord Jr (1999, p. 175).

In the early 60s, the school of administration of Fundação Getulio Vargas began the activities of research and publications group such as the Journal of Business Administration (RAE), being today one of the oldest Brazilian newspaper circulating related to Administration within the enterprise escope, Bertero (2006) highlights. In that time in the mid '60s, the administrative theory "was undergoing controlled development within a tacit agreement of methods, methodologies, analytical perspectives and epistemological basis" (PECI; ALCADIPANI, 2004, p. 10).Despite such initiatives and there being already a controlled development of research in Administration, the importance and intensification of research activity were observed only after the institutionalization of the graduate course in the country (BERTERO, 2006).

What we have noticed, therefore, is that "although it is new as a scientific field in Brazil, research in business administration has quantitatively grown in recent years," Bertero, 
Caldas and Wood Jr. (1999, p. 148) highlight. The union between research, teaching and graduate studies in Bertero's views (2006, p. 99) "explains the increase in scientific production in the last decade."

In this sense, it is also possible to credit such a transformation, according to Kirshbaum, Porto and Ferreira (2004, p.3) to "the role played by Capes, when establishing the scoring academic system and requiring minimum score for faculty researchers," since "Capes' rating system assigns decisive importance to research that results in publications" (BERTERO, 2006, p. 98).Therefore, it is also important to highlight the role that Anpad (National Association of Graduate Studies and Research in Administration) has played in recent years, Bertero (2006) adds.

It was only with the path-breaking work of Machado-da-Silva, Cunha and Amboni (1990) that the administration academy seems to have awakened to the need for a comprehensive review of its production.

\begin{abstract}
From this initial survey, several fields have started making critical statements of this kind, as Marketing (Vieira, 1998, 1999, 2000; Perin et al., 2000; Botelho and Macera, 2000), Information Administration (Hoppen et al., 1998), Production (Bignetti and Paiva, 1997) and Public Administration (Keinert, 2000). What draws attention in virtually all of these studies is the convergence of the conclusion: almost all indicate serious problems in the quality of work (TONELLI et al., 2003, p. 106).
\end{abstract}

In this sense, the quality and applicability of scientific production in administration has been a topic of interest and concern for many scholars in the field, especially in recent years (eg. CARRIERI; LIGHT, 1998; BERTERO, CALDAS; WOOD JR., 1999; PERIN et al., 2000; LOPES; BERNADES, 2001; DAVEL; ALCADIPANI 2002, among others).

Although the focus of analysis of the works carried out by these authors is sometimes different, all studies show a similarity in identifying that the scientific production in Administration is "very fragmented, in which different paradigms are used simultaneously, forming a kind of 'big collage' of ideas and approaches," Lopes and Bernardes (2001, p. 97) highlight. Bertero, Caldas and Wood Jr. (1999, p. 148) also add that domestic production in Administration is "peripheral, epistemologically flawed, methodologically deficient, lacking originality and practice, in large scale, misinformed mimicry."In this sense, Peci and Alcadipani (2004, p. 11) corroborate by the fact that critical analyses on the quality of scientific output in different areas, such as "Organizations, Marketing, Information Administration, Strategy, Public Administration and Human Resources, identified weaknesses in theoretical and methodological standpoints and also about the relevance of the 
contributions of the field. "Thus, the administration seems to be "admittedly lacking an area of higher scientific density" (BERTERO, 2006, p. 101).

Because of the concern about the quality of what is produced in the field of Administration, reflections in academia have been generated according to Antunes et al (2004) and "besides the articles, some panels and roundtables have analyzed from the quality up to the continuity of the works carried out and published nationwide in [...] Administration "(PERIN et al., 2000, p. 1).The Brazilian scientific community in administration seems to have given more attention to the content that has been produced, reflecting, criticizing and analyzing activity that it eventually incorporated in the research itself. That way, it is possible to find important reflective and descriptive works on administration research in the country since the 1980s and which remain until today (BERTERO, 2006, p. 104).

\section{RESEARCH DESIGN}

This work is characterized by being a study on Brazilian literature on internal marketing in the Administration field. We present a methodology of descriptive and executive character inherent to works known as the state of knowledge and that can be characterized as bibliometric studies (FERREIRA, 2002).

The bibliometrics, in this sense, is a tool that allows mapping and generating "different indicators of treatment and management of information and knowledge, (...) necessary for the planning, evaluation and management of science and technology of a certain scientific community or country"(GUEDES; BORSC HIVER 2005, p. 15). Cardoso et al. (2005) add that the bibliometric analysis is an essential part of understanding the process of science, and when such analysis is increased by qualitative research, the results acquire greater scope in interpretation.

The selection of articles for this study met the procedures for collection and analysis followed by Tonelli et al. (2003), who considered the most cited meta-studies in various areas of Enanpad, like Vieira (1998) and Perin et al. (2000).

The selection of articles for this work met the following criteria:

-The databases chosen to extract the corpus of this study took into account the representativity in terms of publications in the area of Administration for the events, as well as rankings by Qualis System of the Higher Education Personnel Improvement Coordination - CAPES (with concept higher or equal to B3) to the main periodicals; 
-The corpus for this study is formed from the recovery of all the articles in the online database: the National Association of Graduate Programs in Business Administration (Anpad) in the period 1997-2012; Scientific Periodicals Electronic Library (SPELL); the Journal of Administration (Rausp) in the period 1977-2012 ${ }^{1}$ (35 years); Electronic Journal of Organizational Management (Gestão.org) in the period 2003-2012; the Journal of Contemporary Administration (RAC) in the period 1997-2012; the Electronic Journal of Administration (REAd) in the period 1995-2012; the journals of EBAPE.BR in the period 2003-2012; Journal of Business Administration (RAE) in the period 1961-2012; the Brazilian Administration Review (BAR - publication of Anpad) in the period 2004-2012 and the Brazilian Business Review (BBR) in the period 2004-2012;

-The rule of completeness ${ }^{2}$ of Bardin (2011) was used to define the corpus. Thus, a temporal cut was not defined a priori to validate the retrieved articles, being considered valid, therefore, every article that appeared in the search results, totaling 13 full and selected articles;

-The search criteria adopted to search from analytical categories that must be present in the title, whose keywords searched were: internal marketing and "endomarketing"3;

-The recovery of the literature was conducted in the period Dec 04 to 11, 2012.

After demarcation of the universe and the collection of articles, it was possible to constitute the corpus of research that covered the entire existence of the theory of internal marketing. "The corpus is the set of documents considered for undergoing the test procedures" (BARDIN, 2011, p. 126).

The content analysis of Bardin (2011, p. 44) was used as a technique for data analysis:

\footnotetext{
A set of analysis techniques of communication that uses systematic and objective procedures to describe the content of the messages. The intent of content analysis is the inference of knowledge concerning production conditions, which inference uses indicators (quantitative or not).
}

\footnotetext{
${ }_{1}^{1}$ Publication suspended from 1967 to 1976.

${ }^{2}$ A total of 35 years of publication in events of the field

${ }^{3}$ Including its variations: "endo-marketing" and "endo marketing"
} 
The categories defined for analysis were: terms (contained in article titles and key words), author and affiliation of authors (number of authors, programs, research groups), references (primary authors, major conferences, periodicals and authors that are sources of citation), methodological profile (nature of work, locus of the study).

Each article was analyzed in terms of its content with the aim of identifying information about the above aspects. The articles are identified, as necessary, throughout the analysis according to the symbols used in the table 1 below.

Table 1 - Symbols for Identification of Articles

\begin{tabular}{l|c}
\hline & Identification of articles \\
\hline Brazilian Business Review (BBR) & BBR_2012 \\
\hline \multirow{2}{*}{ Electronic Journal of Administration (REAd) } & REAd_2002 \\
\cline { 2 - 2 } & REAd_2005b \\
\hline EnANPAD - National Association of Graduate Studies and Research in & EnANPAD_2001 \\
Administration Meeting & EnANPAD_2005 \\
& EnANPAD_2007 \\
\hline EnADI - Information Administration Meeting & EnANPAD_2008 \\
\hline EnGPR - Personnel Management and Labor Relations Meeting & EnANPAD_2011 \\
\hline EMA - Marketing Meeting & EnADI_2009 \\
\hline Scientific Periodicals Electronic Library (SPELL) & EnGPR_2009 \\
\hline
\end{tabular}

Importantly, a decision of the authors that limits the scope of the article lies in the focus of analysis, the context in Administration. Such restriction did not consider the possible articles of related fields, for example, the field of communication, although research has been done in an attempt to recover any items composing the corpus of this study, no studies that met the search criteria defined were found. However the focus given in Administration is justified due to the close relationship of the subject with services marketing, since, according to Berry et al. (1976), internal marketing has been proposed as a solution to the problem of providing consistent high quality services for over 34 years, as indicated above and reinforced herein the dominant application in this field.

The authors' experience in teaching service marketing indicates that there is a substantial theoretical corpus in international academic publications (e.g., Marketing Theory, Journal of Banking Marketing, Journal of Retailing, among others), related to the areas of 
management and marketing, pointing out that internal marketing has been explored in research in these fields of administration (with emphasis on the sectors of retail and service).

\section{DATA ANALYSIS}

The articles were obtained in digital form through the National Association of Graduate Studies and Research in Administration (Anpad), the Scientific Periodicals Electronic (SPELL), the Journal of Administration (Rausp); Electronic Journal of Organizational Management (Gestão.org); the Journal of Contemporary Administration (RAC); the Electronic Journal of Administration (REAd); journals of EBAPE.BR; Journal of Business Administration (RAE); the Brazilian Administration Review (BAR - publication of Anpad) and the Brazilian Business Review (BBR).

It is important to emphasize that, despite the fact that all the periodicals surveyed highlight in their editorial lines that the publication scopes include issues relating to management of organizations and their various areas (including marketing and human resources) there have not been found, according to Table 2 below, items that satisfy the search conditions in most of the investigated periodicals: Journal of Administration (Rausp); Electronic Journal of Organizational Management (Gestão.org), the journals of EBAPE.BR, the Journal of Business Administration (RAE) and the Brazilian Administration Review (BAR). In the database of the Journal of Contemporary Administration (RAC), only one entry for the research was recovered, however the recovered material was classified as bibliographical notes, thus not meeting the search criteria for this study. So the only two periodicals whose search results were satisfactory were the Electronic Journal of Administration (REAd), published by the School of Administration of the Federal University of Rio Grande do Sul, evaluated at level B2 (according to Capes's new classification levels) and the Brazilian Business Review (BBR), published by Fucape Business School, evaluated at level A2 in Qualis/Capes system.

With respect to conference articles, papers from five editions of EnANPAD, one from EnADI, EnGPR and EMA were analyzed. From the eight editions of the conferences analyzed, only one occurred in the central-west region and one in the northeast; the vast majority (six) was in the south-east (table 3 below).

From the three articles retrieved from the SPELL database, just the one published in the Virtual Notebook of Tourism was considered for the corpus, because the context and organizations and did not meet the criterion for Qualis/Capes evaluation (table 4). 
Table 2 - Articles by Periodical/Year

\begin{tabular}{|c|c|c|c|c|}
\hline Periodical & Qualis/Capes $^{4}$ & Year & Issue & $\begin{array}{c}\text { Number of } \\
\text { articles }\end{array}$ \\
\hline Journal of Business Administration (RAE) & $\mathrm{A} 2$ & - & & \\
\hline Brazilian Administration Review (BAR) & $\mathrm{A} 2$ & - & & \\
\hline Brazilian Business Review (BBR) & $\mathrm{A} 2$ & 2012 & Oct - Dec & 01 \\
\hline Journal of Contemporary Administration (RAC) & $\mathrm{A} 2$ & - & - & - \\
\hline Journal of Administration (Rausp) & B1 & - & - & - \\
\hline Journals of EBAPE.BR & B1 & - & - & - \\
\hline \multirow{2}{*}{ Electronic Journal of Administration (REAd) } & \multirow{2}{*}{ B2 } & 2002 & Jul-Aug & 01 \\
\hline & & 2005 & Jan-Feb & 02 \\
\hline $\begin{array}{l}\text { Electronic Journal of Organizational Management } \\
\text { (Gestão.org) }\end{array}$ & B3 & - & - & - \\
\hline TOTAL & & & & 04 \\
\hline
\end{tabular}

Table 3 - Articles by Anpad Event/Place/Year

\begin{tabular}{|c|c|c|c|c|}
\hline Anpad Event & Year & Place & Region & $\begin{array}{c}\text { Number of } \\
\text { articles }\end{array}$ \\
\hline \multirow{5}{*}{$\begin{array}{l}\text { EnANPAD - National Association of Graduate } \\
\text { Studies and Research in Administration Meeting }\end{array}$} & 2001 & Campinas/SP & $S$ & 01 \\
\hline & 2005 & Brasília/DF & $\mathrm{CO}$ & 01 \\
\hline & 2007 & Rio de Janeiro/RJ & SE & 01 \\
\hline & 2008 & Rio de Janeiro/RJ & SE & 01 \\
\hline & 2011 to $\mathrm{da}$ & Rio de Janeiro/RJ & SE & 01 \\
\hline EnADI - Information Administration Meeting & 2009 & Recife/PE & $\mathrm{NE}$ & 01 \\
\hline $\begin{array}{l}\text { EnGPR - Personnel Management and Labor } \\
\text { Relations Meeting }\end{array}$ & 2009 & Curitiba/PR & S & 01 \\
\hline EMA - Marketing Meeting & 2012 & Curitiba/PR & $\mathrm{S}$ & 01 \\
\hline & & & TOTA & 08 \\
\hline
\end{tabular}

Table 4 - Articles Retrieved in the SPELL Database

\begin{tabular}{l|c|c|c|c}
\multicolumn{1}{c|}{ Source: } & Qualis/Capes & Year & Issue & $\begin{array}{c}\text { Number of } \\
\text { articles }\end{array}$ \\
\hline Organizations and context & B4 & 2010 & Jan.-Jun. & 02 \\
\hline Virtual Notebook of Tourism & B1 & 2009 & $\begin{array}{l}\text { Sep.- } \\
\text { Dec. }\end{array}$ & 01 \\
\hline
\end{tabular}

Other aspects call attention: the publications on the subject are recent (they started as of 2001), are not constant (no studies were found in 2003, 2004, 2006 and 2010, for example) nor are they expressive in terms of amount per event or issue of the periodical (all issues / events have only published one article, with the exception of Read's Jan-Feb issue of 2005, which presented two article).

\footnotetext{
${ }^{4}$ At the time of the performance of this study and considering the assessment for the field of Administration.

${ }^{5}$ At the time of the performance of this study and considering the assessment for the field of Administration
} 
The analysis of the authors of the articles (table 5 below) shows that $61.6 \%$ present one or two authors, however the amount of articles that have three or more authors $(38.5 \%)$ is also significant. Given the pressures of Capes's evaluation system, which attaches decisive importance to research that results in publications by publication, researchers that opt for coauthoring increase, therefore, their chances of publication.

Table 5 - Number of Authors per Article

\begin{tabular}{c|c|c|c|c|c}
\hline Articles & $\mathbf{1}$ author & $\mathbf{2}$ authors & 3 authors & More than 3 authors & TOTAL \\
\hline Quantity & 03 & 05 & 02 & 03 & $\mathbf{1 3}$ \\
\hline$\%$ & $23.1 \%$ & $38.5 \%$ & $15.4 \%$ & $23.1 \%$ & $\mathbf{1 0 0 \%}$ \\
\hline
\end{tabular}

Table 6 presents the methodological profile. The published articles are predominantly theoretical and empirical-theoretical in nature, however some considerations on the proportions of this nature can be made for the production of periodicals and Anpad events. The first consideration is that conferences seems to prefer articles of empirical-theoretical nature, since all articles published in the Anpad events can be classified this way. Another consideration is that only two theoretical articles were published in the entire corpus of this study. Such publications were made in periodicals. The most used method was the case study, with qualitative (interviews and focus groups) and quantitative (survey) approaches.

Table 6 - Methodological Profile

\begin{tabular}{c|c|c|c}
\hline Nature & Type of publication & Subtotal & Total \\
\hline \multirow{2}{*}{ Theoretical } & Conference & - & \multirow{2}{*}{02} \\
\cline { 2 - 3 } & Periodical & 02 & \multirow{2}{*}{11} \\
\hline \multirow{2}{*}{$\begin{array}{c}\text { Theoretical- } \\
\text { empirical }\end{array}$} & Conference & 08 & \\
\cline { 2 - 3 } & Periodical & 03 & $\mathbf{1 3}$ \\
\hline
\end{tabular}

The locus (Table 7 below) of the study was predominantly service companies. Only four articles related their studies with the industry. Such data reinforces the importance of the association of internal marketing with the perspective of services marketing.

Table 7 - Locus of the Studies

\begin{tabular}{r|c}
\hline Locus of the study & Quantity \\
\hline Service & 07 \\
\hline Industry & 04 \\
\hline TOTAL & $\mathbf{1 1}$ \\
\hline
\end{tabular}


The following analyses relate to the references used in the articles.

The first analysis was made regarding the bibliographical references of articles retrieved for study. 445 complete references that served as the basis for subsequent analyses were recorded. According to the information in Table 8 below, it can be seen that there was no significant variation in the average number of references of articles published in conferences from those published in periodicals (34.38 and 34.0, respectively).

Table 8 - Number of Citations per Publication and Average Citations per Article

\begin{tabular}{|c|c|c|c|}
\hline & $\begin{array}{l}\text { Quantity of } \\
\text { References }\end{array}$ & $\begin{array}{c}\text { Average } \\
\text { by article }\end{array}$ & $\begin{array}{c}\text { Number of } \\
\text { articles }\end{array}$ \\
\hline Conference & 275 & 34.38 & 08 \\
\hline Periodical & 170 & 34.0 & 05 \\
\hline TOTAL & 445 & - & 13 \\
\hline
\end{tabular}

Table 9 below shows the top 12 works cited in the articles. It is worth drawing attention to the fact that, out of the 445 citations, the most cited works in the articles were Kotler and Grönroos, with eight and seven citations, respectively. The latter author appears twice in the table below with two different works. What we can see is that there is a scattering of articles used, and there is no framework of reference for internal marketing in the field since Kotler is not exactly a specific author who deals with internal marketing.

Table 9 - Major Works Cited ${ }^{6}$

\begin{tabular}{|c|c|c|}
\hline Ranking & Work & $\begin{array}{l}\text { Quantity of } \\
\text { References }\end{array}$ \\
\hline \multirow{2}{*}{1} & KOTLER, P. Marketing administration. & 08 \\
\hline & GRÖNROOS, C. Marketing: management and services & 07 \\
\hline 2 & CERQUEIRA, W. "Endomarketing": Education and Culture for Quality & 29 \\
\hline \multirow{4}{*}{3} & $\begin{array}{l}\text { BERRY, L.; PARASURAMAN, A. Marketing Services: Competing through } \\
\text { Quality }\end{array}$ & \multirow{4}{*}{04} \\
\hline & BRUM, A. M. Breathing "Endomarketing" & \\
\hline & BRUM, A.M. "Endomarketing" & \\
\hline & $\begin{array}{l}\text { BANSAL, H.; MENDELSON, M.; SHARMA, B. Impact of Internal } \\
\text { Marketing Activities on External Marketing Outcomes }\end{array}$ & \\
\hline
\end{tabular}

\footnotetext{
${ }^{6}$ After reference to the works of Brum, the next Works were referenced three or fewer times. Thus, we preferred to indicate only the Works with up to four references
} 


\begin{tabular}{l|l|l|}
\hline & $\begin{array}{l}\text { GEORGE, W. Internal marketing and organizational behavior: a partnership } \\
\text { in developing customer Conscious employees at Every Level }\end{array}$ & $\begin{array}{l}\text { GRÖNROOS, Christian. Internal marketing: an integral part of marketing } \\
\text { theory. }\end{array}$ \\
\cline { 2 - 3 } $\begin{array}{l}\text { RAFIQ, M.; AHMED, P. K. Advances in the internal marketing concept: } \\
\text { definition, synthesis and extension. }\end{array}$ & $\begin{array}{l}\text { VAREY, R. Internal Marketing: A Review and some Interdisciplinary } \\
\text { Research Challenges. }\end{array}$ \\
\hline
\end{tabular}

A ranking was made regarding the most referenced authors, regardless of the work used in the articles (Table 10 below). In line with the work of Bertero (2006); Bertero and Keinert (1994); Vergara Jr and Carvalho (1995) and Vergara and Pinto (2001), which emphasize the overuse of theories, models and foreign authors, the most cited author is Christian Grönroos, who is Finnish. However, contrary to these authors, the second most referenced author is Brazilian (Analisa de Medeiros Brum), and the next ten most referenced authors, only two are not from the field of marketing. Another important consideration is about the use of the term "endomarketing" $\mathrm{x}$ internal marketing. From the six works of the Brazilian author that were referenced, five have endomarketing in their titles, and only one presents the term internal marketing.

Table 10 - Top Authors Referenced

\begin{tabular}{|c|c|c|}
\hline Ranking & Author & $\begin{array}{l}\text { Quantity of } \\
\text { References }\end{array}$ \\
\hline 1 & Christian Grönroos & 14 \\
\hline \multirow{2}{*}{2} & Analisa de Medeiros Brum & \multirow{2}{*}{13} \\
\hline & Mohammed Rafiq e Pervaiz K. Ahmed & \\
\hline 3 & Philip Kotler & 09 \\
\hline \multirow{2}{*}{4} & Saul Faingaus Bekin & \multirow{2}{*}{07} \\
\hline & Leonard Berry & \\
\hline 5 & Wilson Cerqueira & 06 \\
\hline \multirow{3}{*}{6} & Evert Gummesson & \multirow{3}{*}{05} \\
\hline & William R George & \\
\hline & Richard J. Varey & \\
\hline
\end{tabular}

The analysis of the terms of the selected articles was performed by identifying the key search words (either internal marketing or "endomarketing") in the titles of articles. The results are shown in Table 11 below. 
Table 11 - Most Frequent Term in Articles' Titles

\begin{tabular}{c|c|c|c}
\hline \multicolumn{1}{c|}{ Terms } & Type of publication & Subtotal & \multirow{2}{*}{ Total } \\
\hline \multirow{2}{*}{ "Endomarketing" } & Conference & 05 & \multirow{2}{*}{06} \\
\cline { 2 - 3 } & Periodical & 01 & \\
\hline \multirow{2}{*}{ Internal Marketing } & Conference & 03 & \multirow{2}{*}{07} \\
\cline { 2 - 3 } & Periodical & 04 & \\
\hline
\end{tabular}

The presence of both subjects in the same title was not identified, so the total of the table 11 is exactly equal to the total number of selected items.

What we see in the analysis of the articles is that, in general, the use of the term "endomarketing" appears only as a synonym for internal marketing, as an alternative to the translation of internal marketing. Thus, the authors sometimes use one rather than use the other only as a strategy to write the text, without questioning the existence of such a variety of terms for the same concept. But they use foreign authors (BERRY, 1981; BERRY, PARASURAMAN, 1995; GRÖNROOS, 1995; RAFIQ, AHMED, 2000) and their works on the subject in order to contextualize the purpose and concept of internal marketing.

Excerpts of articles allow you to understand such a situation ${ }^{7}$ :

•"The "endomarketing", or internal marketing according to Grönroos (1995) and Brum (1998) is to be understood as ..."(EnANPAD, 2011);

•"The internal marketing, also called "endomarketing", is a set of practices introduced and improved ..."(REAd, 2002);

-"From these findings, a new field of study emerged: the internal marketing (or "endomarketing")" (EnANPAD, 2001);

•"The "endomarketing", also known as internal marketing, consists in projects or initiatives that aim to get ..."(EnADI, 2009);

-"The internal marketing or "endomarketing" is a form of management that integrates the functions of the organization ..."(EnANPAD, 2007);

•"In Brazil, the literature of internal marketing (also called "endomarketing") is still scarce ..." (EnANPAD, 2005);

\footnotetext{
${ }^{7}$ See research design section on page 7 on identification of articles
} 
-"The internal marketing, which is also known by the terminology "Endomarketing" consists of an 'Umbrella' concept ..."(REAd, 2005a).

It is noted that such discussion on the best term to use is not restricted to the English language. Varey and Lewis (1999) add that there is strong resistance among some scholars and practitioners regarding the use of the term internal marketing since such term suggests that the mechanism of change management that is being described is the exclusive property of the marketing managers. The terms "internal relationship marketing", "internal relationship management" or "internal social management process" are proposed as an alternative to foreign literature. Papasolomou (2006) revisited the literature and warns that there is a variety of formats for the implementation of internal market, which confuse and create ambiguity instead of clarity and understanding.

From the articles analyzed:

- Only four of them do not make use of foreign classical authors, focusing the theoretical discussion on the topic only on Brum (1998, 2000, 2003), Bekin (1995, 2004, 2005) and Cerqueira (1994, 1999, 2005) (Brazilian authors that emphasize the use of the term "endomarketing");

-Seven of them present misinterpretation of the concept of internal marketing. Part of such misconception is due to the fact that it is often the mixture of what has been discussed in foreign and Brazilian literatures, prevailing the discussion of national literature. In all seven of these articles, there is a frequent exchange between the terms internal marketing and "endomarketing" as if they were synonyms. Excerpts of articles allow you to understand such a situation:

- "Iinternal marketing can be defined as a set of actions that aims to make objectives, goals and results common among employees of a company" (EnANPAD, 2007);

- "Endomarketing", also known as internal marketing, consists in projects or initiatives that seek to obtain or even redeem user awareness and emphasize the importance of their support and collaboration so as organizational change can be successfully implemented" (EnADI, 2009); 
- "The internal marketing, also called "endomarketing" is a set of practices introduced and improved in the organization, which aims to obtain, or raise, the commitment of its employees" (REAd, 2002);

- "Endomarketing" is defined as managed actions in marketing ethically directed to internal public (employees) of organizations and companies focused on profit, non-profit and governmental organizations and companies of the third sector, observing community and environmental responsibility actions" (EnANPAD, 2008) .

-Three of them call attention to the fact that there is a range of concepts of internal marketing causing confusion since there is no unified concept of what is meant to be internal marketing. Excerpts of articles allows us to understand such a situation:

- "There is a lot of confusion in the literature as to exactly what is IM, which should be done, how it should be done and who should do it. One of the main problems contributing to this is that there is no unified concept of what is understood by IM"(BBR, 2010);

- "This range of different definitions of internal marketing entails the nonexistence of a conceptualization considered dominant on the subject" (EnANPAD, 2005);

- "The concept of internal marketing has no unanimity among scholars" (REAd, 2002).

-In four of them, although the authors discuss the various views on the concept, it is clear and referenced according to the international literature, and in three, the authors state that the most complete concept is the one by Rafiq and Ahmed (2000).

Importantly, the term endomarketing is owned and of exclusive use of S. Bekin \& Consultores Associados Ltda., trademark registration (No. 815990995), awarded by the National Institute of Industrial Property (INPI), autarchy linked to the Ministry of Industry and Trade on January 3, 1995 (INKOTTE, 2000). 


\section{FINAL THOUGHTS}

This work proposed to analyze how the internal marketing theme has been dealt with in the main periodicals of Administration and the database of the National Association of Graduate Programs in Business Administration (Anpad) and Scientific Periodicals Electronic Library (SPELL), with the objective of contributing to the understanding of how academics are studying internal marketing in the Brazilian context. Through the analysis of the articles, it was possible to identify, for example, the most used terms in the titles of works, authors who publish the most, the main references used and most referenced authors. The main contribution of a study like this one is to periodically monitor the scope of the research developed during a specific period of time, because the quantitative growth does not necessarily imply criteria for advancement in the field of research.

This work reveals that the Brazilian scientific production on internal marketing is very specific and, in some cases, such as periodicals of Administration, surprisingly non-existent, since from the eight periodicals studied only two were articles that met the search criteria for this job. This aspect allows to view various concerns, the most significant of which is: for what reason internal marketing has not received - at least with respect to periodicals and national conferences of Administration - the attention it deserves?

This study reveals that there is a significant predominance of references whose definitions of internal marketing are actually more appropriate. Unveiling the apparent mistake in using the concept of "endomarketing" as a synonym for internal marketing emphasizes the need to avoid the use of the first, since the literature is clear on the use of a single term - internal marketing. Note that there is a low frequency of reference to the seminal authors on internal marketing which serves as a warning to the (current and future) Brazilian researchers.

In general, what we can see is that the term "endomarketing", when used, is considered synonymous with internal marketing. The interpretation, however, differs from foreign literature considered when only Brazilian authors are considered. For reasons of loss in translation or lack of access to works of foreign authors, the fact is that articles that considered only Brazilian authors presented a distorted concept and application of internal marketing.

Given the above, it is important to explore the concept of internal marketing in terms of its contribution to the Academia. Accordingly, before the surveys and diagnostics, it is important to put on record the importance of developing more articles on the subject without, 
however, "brazilianizing" the understanding of internal marketing, using "endomarketing" as a synonym whose essence does not follow the basic constructs of internal marketing, which could result in erroneous analysis.

Importantly, due to the limitations of this study (considering only eight periodicals in Administration, the events organized by Anpad and the time period analyzed, although the entire digital collection available has been contemplated); the results presented here cannot be generalized to other events or periodicals. The results relate to the standards of the periodicals and conferences analyzed; however, for being academically recognized, this study is able to contribute to the understanding of scientific literature on internal marketing in Administration.

\section{REFERENCES}

ANTUNES, E. D. et al. Trajetória das dissertações em gestão de pessoas de um curso de pósgraduação do sul do país: caminhos de uma tradição de pesquisa e atalhos para a renovação. In: ENCONTRO DOS PROGRAMAS DE PÓS-GRADUAÇÃO EM ADMINISTRAÇÃ̃O (ENANPAD), 28., 2004, Curitiba (PR). Anais... Curitiba: ANPAD, 2004.

BARDIN, L. Análise de conteúdo. São Paulo: Edições 70, 2011.

BERRY, L. L. The employee as customer. Journal of Retail Banking, v. 3, p. 25-8, mar. 1981.

BERRY, L. L.; HENSEL, J. S.; BURKE, M. C. Improving retailer capability for effective consumerism response. Journal of Retailing, v. 52, n. 3, p. 3-14, 1976.

BERRY, L. L.; PARASURAMAN, A. Marketing services: competing trough quality. New York: The Free Press, 1991.

BERTERO, C. O. Ensino e pesquisa em administração. São Paulo: Thomson Learning, 2006.

BERTERO, C. O.; CALDAS, M. P.; WOOD JUNIOR, T. Produção científica em administração de empresas: provocações, insinuações e contribuições para um debate local. RAC, v. 3, n. 1, jan./abr. 1999.

BERTERO, C. O.; KEINERT, T. M. M. A evolução da análise organizacional no Brasil: 1961-93. Revista de Administração de Empresas, v. 34, n. 3, p. 81-90, maio/jun. 1994.

CALDAS, M.; TONELLI, M. J.; LACOMBE, B. M. B. Espelho, espelho meu: meta-estudo da produção científica em recursos humanos nos ENANPADs da década de 90. In: Encontro dos Programas de Pós-Graduação em Administração (ENANPAD), 26., 2002, Campinas (SP). Anais... Campinas: ANPAD, 2002.

CALDAS, M. P.; TINOCO, T. Pesquisa em gestão de recursos humanos nos anos 1990: um estudo bibliométrico. Revista de Administração de Empresas [online], v. 44, n. 3, p. 100114, 2004. 
CARDOSO, R. L. et al. Pesquisa científica em contabilidade entre 1990 e 2003. Revista de Administração de Empresas, São Paulo, v. 45, n. 2, p. 34-45, abr./jun. 2005.

CARRIERI, A. P.; LUZ, T. R. Paradigmas e metodologias: não existe pecado o lado debaixo do equador. In: ENCONTRO DOS PROGRAMAS DE PÓS-GRADUAÇÃO EM ADMINISTRAÇÃO (ENANPAD), 22., 1998, Foz do Iguaçu (PR). Anais... Foz do Iguaçu: ANPAD, 1998.

DAVEL, E.; ALCADIPANI, R. Estudos críticos em Administração: reflexões e constatações sobre produção brasileira. In: ENCONTRO DE ESTUDOS ORGANIZACIONAIS (ENEO), 2002, Recife (PE). Anais... Recife: ANPAD, 2002.

FARIAS, S. A. Marketing interno (MI): uma revisão da literatura e proposições de pesquisa para a excelência nos serviços. Brazilian Business Review, Vitória, v. 7, n. 2, p. 106-122, maio/ago. 2010.

FERREIRA, N. S. A. As pesquisas denominadas "estado da arte". Educação \& Sociedade, ano 23, n. 79, ago. 2002.

GUEDES, V.; BORSCHIVER, S.. Bibliometria: uma ferramenta estatística para a gestão da informação e do conhecimento, em sistemas de informação, de comunicação e de avaliação científica e tecnológica. In: ENCONTRO NACIONAL DE CIÊNCIA DA INFORMAÇÃ̃O, 2005, Salvador (BA). Anais... Salvador: CINFORM, 2005. Disponível em: <http://dici.ibict.br/archive/00000508/>. Acesso em: 14 nov. 2011.

GREENE, W. E.; WALLS, G. D.; SCHREST, L. J. Internal marketing: the key to external marketing success. The Journal of Services Marketing, v. 8, n. 4, p. 5-13, 1994.

GRÖNROOS, C. On defining marketing: finding a new roadmap for marketing. Marketing Theory, v. 6, n. 4, p. 395-417, 2006.

Relationship marketing: the strategy continuum. Journal of the Academy of Marketing Science, v. 23, p. 252-254, 1995.

INKOTTE, A. L. Endomarketing: elementos para construção de um marco teórico. 2000. Dissertação (Mestrado) - Programa de Pós-Graduação em Engenharia da Produção, Universidade Federal de Santa Catarina (UFSC), Florianópolis (SC), 2000.

KIRSHBAUM, C.; PORTO, E. C.; FERREIRA, F. C. M. Neo-institucionalismo na produção acadêmica em Administração. RAE-Eletrônica, v. 3, n. 1, mai./jun. 2004.

KURTZ, D.; CLOW, K. Services marketing. New York: John Wiley \& Sons, 1996.

LEÃO, A. L. M. S. et al. Marketing interno e a formação de sujeitos reflexivos.

Organizações em contexto, ano 6, n. 11, jan./jun. 2010.

LINGS, I. N.; BROOKS, R. F. Implementing and measuring the effectiveness of internal marketing. Journal of Marketing Management, v. 14, p. 325-351, 1998.

LOPES, H. E. G.; BERNARDES, P. Ampliando a análise da produção científica em administração: o indutivo versus o dedutivo. Economia \& Gestão, v. 1, n. 2, jul./dez. 2001. 
A AD -DA-SI A, . . N A, . . A NI, N. $r$ ani a es o estado da arte da produ o a ad mi a no rasi . In EN N R D S PR RA AS DE P SGRADUAÇÃO EM ADMINISTRAÇÃO (ENANPAD), 14., 1990, Florianópolis (SC). Anais... Florianópolis: ANPAD, 1990.

NORMANN, R. Management for growth. Chichester: Wiley, 1977.

Administração de serviços: estratégia e liderança na empresa de serviços. São Paulo: Atlas, 1993.

ÓRFÃO, C. O efeito do marketing interno no envolvimento e comprometimento organizacional e a influência destes na satisfação e desempenho individual: o caso do Banco Comercial Português S.A. 2010. Dissertação (Mestrado) - Programa de PósGraduação em Estratégia Empresarial, Faculdade de Economia da Universidade de Coimbra, Coimbra (PT), 2010.

PAPASOLOMOU, I. Can internal marketing be implemented within bureaucratic organisations? International Journal of Bank Marketing, v. 24, n. 3, p. 194-212, 2006.

PECI, A.; ALCADIPANI, R. Demarcação científica: uma reflexão crítica. In: ENCONTRO DOS PROGRAMAS DE PÓS-GRADUAÇÃO EM ADMINISTRAÇÃO (ENANPAD), 28., 2004, Curitiba (PR). Anais... Curitiba: ANPAD, 2004.

PERIN, M. G. et al. A pesquisa survey em artigos de marketing nos ENANPADs da década de 90. In: ENCONTRO DOS PROGRAMAS DE PÓS-GRADUAÇÃO EM ADMINISTRAÇÃO (ENANPAD), 24., 2000, Florianópolis (SC). Anais... Florianópolis: ANPAD, 2000.

RAFIQ, M.; AHMED, P. K. Advances in the internal marketing concept: definition, synthesis and extension. The Journal of Services Marketing, Santa Barbara, v. 14, n. 6, p. 449, 2000.

ROMANOWSKI, J. P.; ENS, R. T. As pesquisas denominadas do tipo "estado da arte" em educação. Diálogo Educ., v. 6, n. 19, p. 37-50, set./dez. 2006.

SOARES, M. B.; MACIEL, F. Alfabetização. Brasília: MEC/INEP/COMPED, 2000.

TEIXEIRA, P. M. M.; MEGID NETO, J. Investigando a pesquisa educacional: um estudo enfocando dissertações e teses sobre o ensino de Biologia no Brasil. Investigações em Ensino de Ciências, v. 11., p. 261-282, 2006.

TONELLI, M. J. et al. Produção acadêmica em recursos humanos no Brasil: 1991-2000. Revista de Administração de Empresas, São Paulo, v. 43, n. 1, jan./mar. 2003.

VAREY, R. J.; LEWIS, B. R. A broadened conception of internal marketing. European Journal of Marketing, v. 33, n. 9/10, p. 926-944, 1999.

VERGARA, S. C.; CARVALHO JUNIOR., D. Nacionalidade dos autores referenciados na literatura brasileira sobre organizações. Revista Brasileira de Administração

Contemporânea, v. 1, 1995. 
VERGARA, S. C.; PINTO, M. C. S. Referências teóricas em análise organizacional: um estudo das nacionalidades dos autores referenciados na literatura brasileira. Revista de Administração Contemporânea, Curitiba, v. 5, n. esp., 2001.

VIEIRA, F. G. D. Por quem os sinos dobram? Uma análise da publicação científica na área de marketing do Enanpad. In: ENCONTRO DOS PROGRAMAS DE PÓS-GRADUAÇÃO EM ADMINISTRAÇÃ̃O (ENANPAD), 22., 1998, Foz do Iguaçu (PR). Anais... Foz do Iguaçu: ANPAD, 1998. 